\title{
REPRESENTING RAPE - LANGUAGE AND SEXUAL CONSENT
}

\section{Susan Ehrlich}

Routledge, New York

2001, 174 pages

Paperback \& Hard cover

ISBN 0-415-20522-0 (pbk)

ISBN 0-415-20522-0 (hbk)

Ehrlich cuts right through and beyond linguistic jargon to reach to the bone and marrow of both scientific and ordinary users of language by revealing how language is used by those in power to keep them in power. Is there a need for such acute surgery in a South African context, and in particular in an SANDF context?

Even though South African women seem to be bridging the power divide, with thirty percent of South African parliamentarians being women, and the minister of the Department of Defence and Military Veterans being a woman too, South Africa still rates second of all countries for reported rape. Legal experts agree that female defendants are tried in mainly male-oriented environments. ${ }^{1}$ In 2010 , South African benches were still largely male-dominated, with only 49 of 216 permanent judges being women. ${ }^{2}$

In the military context, large-scale rape and other forms of violent assault against women are often synonymous with armed conflict, especially in civilmilitary conflicts, the kind for which the SANDF aims to seek resolutions. Is the typical SANDF soldier suitably equipped for such an important role? In-depth interviews with female SANDF soldiers from all arms of service revealed that sexual harassment in its various forms continues to plague the SANDF working environment even though all forms of sexual harassment, or abuse of power for

Scientia Militaria, South African Journal of Military Studies, Vol 40, $\mathrm{Nr} 1,2012$, pp. 146-148. doi: $10.5787 / 40-1-990$ sexual or other reasons are offences punishable under the Military Disciplinary Code. $^{3}$ 
forces are sanctioned to kill and destroy to protect their country's sovereignty, harming and killing beyond reasonable force and looting people as sex objects are never legally sanctioned. Yet, it happens ... and court martials follow ... and justice is sought. Ehrlich reveals with surgical sharpness and accuracy how the use and abuse of language, and the innate bias of all languages towards maleness, are pivotal to every legal context. Military legal procedures are no different. In DoDMV context, for example, the military legal division remains a largely male-dominated environment. Military legal experts defending or prosecuting soldiers charged for allegedly committing sexual offences, especially those occurring during civilmilitary conflicts, often have nothing but linguistic representations of reality to determine a verdict. The magnitude of the personal and diplomatic consequences of a verdict of guilty is likely to elicit countless incidents of non-agentive language usage, largely employed by the alleged offender and his or her defender, thus working largely against justice.

Ehrlich reveals not only the gender non-representivity of judicial benches, but also, and especially, the male-biased linguistic constructs through which these predominantly male judges conventionally try to reach an "objective" verdict. Men are accredited for "creat[ing] language, thought, and reality", 4 the same language through which the reality of male-on-female rape has to be recreated in a court of law in order to reach a fact-based, gender-unbiased verdict.

Representing rape is based on a verbatim account of a university tribunal and the eventual court case against a male sex offender, an alleged male rapist. It targets readers on both ends of physical, essentially sexual, abuse. It targets in particular the subsequent male dominated legal processes, and then the use or abuse, wittingly or unwittingly, of existing language as well as uncanningly spontaneous, yet effective linguistic defence strategies to construct non-agency or non-liability and ultimately achieve non-agency or innocence.

Ehrlich manages to captivate and pull the reader along towards an introspection of his (mainly) and her witting or unwitting application of elements of non-agency, viz. mitigating (euphemising), obscuring (concealing), eliminating (removing) or diffusing (sharing) liability, in particular towards those we supervise, govern, manage, lead, rule or control.

The blurb to Representing rape sums it up perfectly: "Ehrlich shows how culturally dominant notions about rape percolate through the talk of sexual assault cases in a variety of settings and ultimately shape their outcome." ${ }^{5}$ Reading this 
book will assist military legal experts in reaching verdicts which are indeed expertly non-biased. It will also move common users of language in any context to take responsibility for what they say, because the words we use speak either life or death upon the patients of our statements.

If the currency of soldiers is indeed "murder, rape and pillage", ${ }^{6}$ senior leadership of defence forces globally, and the SANDF in particular, should also read and internalise the message of this book. It hurts, because it cuts through to the masculine nerve. It heals, because it generates an acute awareness of life on the receiving end of that extremely powerful human weapon - language. It liberates, for the same reasons. South Africans in general know what it is like to be excluded and hurt through language. South African men, in particular, should allow this book to inspect and verbalise what they say, and how and why they say it. Its real value lies in its ability to compel readers, civilian as well as military, to inspect, and ultimately change their behaviour for the greater good of man [sic].

Cdr (Dr) Gerhard van Zyl, Department of Languages and Culture, Faculty of Military Science, Stellenbosch University

\section{Endnotes}

${ }^{1}$ Nabeer, A. "Jordan: Legal experts call for gender-sensitive courts". Talal Abu Ghazaleh Legal, June 2010, 4.

<http://www.tag-legal.com/UploadFiles/TAGlegal\%20Newsletter\%20June\%202010.pdf> Accessed on 4 April 2012.

${ }^{2}$ De Vos, P. "Where are all the women judges?" Constitutionally speaking. April 2010. <http://constitutionallyspeaking.co.za/where-are-all-the-womenjudges/> Accessed on 4 April 2012.

${ }^{3}$ Stott, N. Gender violence in the SANDF. From the SADF to the SANDF: Safeguarding South Africa for a better life for all? Violence and Transition Series, Vol. 7. CSVR. 2002.

${ }^{4}$ Spender, D. Man made language. New York: Routledge. 1985. 143.

${ }^{5}$ Representing Rape: Back cover book review by Deborah Cameron.

${ }^{6}$ Lee, R. "A night in the life of a woman in Fizi". Open Society Initiative for Southern Africa. July 2011, <http://www.osisa.org/law/blog/night-lifewoman-fizi> Accessed on 4 April 2012. 